\title{
UJI TOKSISITAS EKSTRAK DAUN JERUJU Acanthus ilicifolius TERHADAP Artemia salina Leach.
}

\section{Eva Johannes dan Sjafaraenan}

\section{Departemen Biologi Fakultas Matematika dan IImu Pengetahuan Alam Universitas Hasanuddin, Makassar}

evayohannes@unhas.ac.id dan enan.gidinnur@gmail.com

\begin{abstract}
Abstrak
Jeruju Acanthus ilicifolius adalah tumbuhan mangrove yang memiliki berbagai potensi dalam bidang pangan dan kesehatan. Untuk dikembangkan sebagai tanaman obat perlu dilakukan penelitianlebih lanjut tentang bioaktivitas ekstrak daun jeruju terhadap A. Salina sebagai uji awal. Penelitian ini bertujuan untuk mengetahui toksisitas ekstrak daun A.illicifolius terhadap artemia salina L. Pengambilan sampel di Karst Ramang Ramang Kabupaten Maros Provinsi Sulawesi Selatan. Uji toksisitas dilakukan di lakukan di laboratorium Biokimia Departemen Kimia Fakultas MIPA Unhas, dengan menggunakan metode Brine Shrimp Lethality Test (BSLT). Hasil yang diperoleh ekstrak daun jeruju $A$. ilicifolius memiliki bioaktivitas tinggi dengan nilai $\mathrm{LC}_{50}=7,56 \mu \mathrm{g} / \mathrm{mL}$. Diharapkan jeruju $A$. llicifolius dapat dikembangkan sebagai tanaman obat yang memiliki potensi dalam mengobati penyakit.
\end{abstract}

Kata kunci : toksisitas, ekstrak, Jeruju Acanthus ilicifolius, Artemia salina Leach.

\begin{abstract}
Jeruju Acanthus ilicifolius is a mangrove plant wich has various potentials in the field of food and health. To be developed as a medicinal plant futher research is needed on the bioactivity of $A$.ilicifolius leaf extract against $A$. salina Leach as a preliminary test. This study aims to determine toxicity A.ilicifoliusleaf extract on $A$. salina $\mathrm{L}$. Sampling in Karst Raamang Ramang Kabupaten Maros South Sulawesi. Toxicity test is done in the laboratory of Biochemistry Department of Chemistry Faculty of Mathematics and Natural Sciences Unhas, using the Brine Shrimp Lethality Test (BSLT) method. The results obtainedjeruju A.ilicifolius leaf extract has high bioactivity with value $\mathrm{LC}_{50}=7.56 \mu \mathrm{g} / \mathrm{mL}$. Expected jeruju A. ilicifolius can be developed as a medicinal plant that has potential in treating the disease.
\end{abstract}

Keywords : Toxicity, extract, Jeruju Acanthus ilifolius, Artemia salina Leach. 


\section{Pendahuluan}

Jeruju Acanthus ilicifolius sebagai tanaman vegetasi mangrove, ditemukan tumbuh pada semua jenis tanah, terutama daerah berlumpur sepanjang tepi sungai, toleran terhadap naungan (Kovendan dan Murugan 2011). Acanthus ilicifolius memiliki bunga yang indah sehingga dapat digunakan sebagai tumbuhan hias atau tumbuhan ornamental, selain itu digunakan sebagai bioindikator pencemaran. Berlimpahnya tumbuhan jeruju pada vegetasi mangrove tidak mengurangi potensinya untuk dimanfaatkan masyarakat sebagai tanaman obat maupun penghasil bahan makanan seperti kerupuk dan minuman teh. Berdasarkan hasil penelitian Johannes dan Sri Suhadiyah (2016), ekstrak daun jeruju mengandung senyawa flavonoid, polivenol dan kumarin.Flavonoid dan polivenol tergolong senyawa yang memiliki fungsi sebagai antioksidan, menurut Ann Lila M., (2004) antioksidan polivenol dapat mengurangi resiko penyakit jantung dan kanker. Juga mengurangi resiko penyakit alzheimer ( Arts et al, 2005). Senyawa kumarin merupakan antibakteri yang dapat merusak sel dengan membentuk pori-pori dinding sel bakteri sehingga menyebabkan kematian sel (Widodo $d k k$, 2012). Untuk mengetahui bioaktivitas ekstrak daun jeruju agar dapat dikembangkan sebagai tanaman obat, maka perlu dilakukan penelitian uji toksisitas. Penelitian ini bertujuan untuk mengetahui toksisitas ekstrak daun jeruju $A$. Ilicifolius terhadap $A$. Salina L. Uji toksisitas terhadap $A$. Salina, ini merupakan penelitian pendahuluan untuk mengetahui apakah ekstrak daun jeruju bersifat toksik terhadap A. Salina, yang selanjutnya dapat dikembangkan dalam uji antikanker.

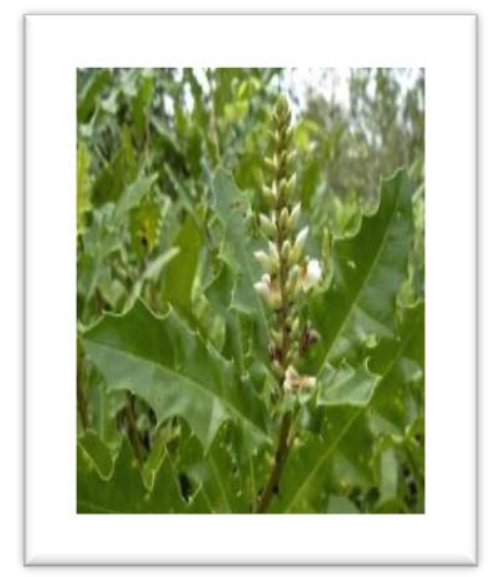

Klasifikasi :

Kingdom : Plantae

Kelas : Magnoliopsida

Ordo : Lamiales

Familia : Acanthaceace

Genus : Acanthus

Species : Acanthus ilicifolius L. (Dharya dkk, 2013)

Gambar 1. Jeruju ( Acanthus ilicifolius) 


\section{Metode Penelitian}

Ekstrak daun Jeruju A.ilicifolius menggunakan metode maserasi, sedangkan untuk uji antimitotik pada $A$. Salina Leach menggunakan metode Brine Shrimp Lethality test (BSLT).

\section{Metode Kerja}

\section{Esktrak daun jeruju Acanthus ilicifolius}

Daun Jeruju yang telah dikeringkan sebanyak $500 \mathrm{gram}$ di potong halus kemudian direndam dengan pelarut metanol sebanyak (1:1) disimpan selama 1 X 24 jam kemudian disaring, hal ini di ulangi sebanyak 3 kali . filtrat yang diperoleh selanjutnya di evaporasi sehingga diperoleh maserat kental.

\section{Uji Brine Shrimp Lethality Test (BSLT)}

Uji BSLT dilakukan sesuai (Meyer et al, 1982). Senyawa uji daalam flakon dilarutkan dengan air laut secukupnya dengan bantuan vortex. Sepuluh ekor larva $A$. Salina dimasukkan secara random ke dalam flakon yang telah berisi senyawa uji dan ditambahkan air laut sampai volume $5 \mathrm{~mL}$. Dibuat suspensi yeast $0.6 \mathrm{mg} / \mathrm{mL}$ dan ditambahkan ke dalam tiap flakon masing-masing 1 tetes sebagai makanan . setelah 24 jam jumlah larva yang hidup dihitung dengan bantuan kaca pembesar dan prosentasi kematian dihitung, $\mathrm{LC}_{50}(\mu \mathrm{g} / \mathrm{mL})$ dihitung dengan analisis probit.

\section{Hasil dan Pembahasan}

Hasil uji toksisitas dengan metode BSLT dengan menggunakan konsentrasi 5 $\mu \mathrm{g} / \mathrm{mL}, 10 \mu \mathrm{g} / \mathrm{mL}, 15 \mu \mathrm{g} / \mathrm{mL}$. Diperoleh hasil pada Tabel 1 .

Tabel 1. Hasil uji BSLT

\begin{tabular}{|c|c|c|c|c|l|}
\hline $\begin{array}{l}\text { Konsentrasi } \\
\mu \mathrm{g} / \mathbf{m L}\end{array}$ & $\begin{array}{c}\text { log } \\
\text { konsentrasi }\end{array}$ & $\begin{array}{c}\% \\
\text { Kematian }\end{array}$ & $\begin{array}{l}\text { Angka } \\
\text { Probit }\end{array}$ & Persamaan garis & $\begin{array}{l}\mathbf{L C}_{50} \\
\boldsymbol{\mu g} / \mathbf{m L}\end{array}$ \\
\hline 5 & 0,701 & 43 & 4.87 & & \\
\cline { 1 - 4 } 10 & 1,10 & 58 & 5.25 & $\begin{array}{r}\mathrm{Y}=1,196 \mathrm{X}+3.987 \\
\mathrm{r}=0.998\end{array}$ & 7.56 \\
\hline 15 & 1.27 & 68 & 5.62 & \\
\hline
\end{tabular}


Dilihat dari hasil uji BSLT nilai $\mathrm{LC}_{50}=7.56 \mu \mathrm{g} / \mathrm{mL}$ menunjukan nilai toksisitas yang tinggi. Suatu senyawa dikatakan berpotensi untuk dikembangkan sebagai antikanker apabila diketahui mempunyai nilai $\mathrm{LC}_{50} \leq 30 \mu \mathrm{g} / \mathrm{mL}$. ( Meyer et al, 1982). Oleh sebab itu dapat dikatakan daun jeruju memiliki sifat toksisitas yang tinggi terhadap a. Salina sehingga dapat dikembangkan lebih lanjut sebagai antikanker. Sesuai dengan pendapat Carballo et al (2002), bahwa senyawa yang toksik terhadap $A$. salina, juga akan bersifat toksik terhadap sel kanker uji, sehingga uji BSLT direkomendasikan sebagai uji skrining perolehan senyawa bioaktif.

\section{Kesimpulan}

Ekstrak daun jeruju Acanthus ilicifolius memiliki sifat toksisitas yang tinggi terhadap Artemia salina Leach dengan nilai $\mathrm{LC}_{50}=7.56 \mu \mathrm{g} / \mathrm{mL}$.

\section{Daftar Pustaka}

1. Arts L.C. and P. Chollman., 2005. Pholiphenols and Disease Risk in Epidemiologic studies. Am. J. clin nutr.

2. Carballo, J., Hermandez, India, Z.L., Perez, P., and Garcia-Gravalos, M.D., 2002, A comparison between two brine shrimp assays to detect in vitro cytotoxicity in marine natural products, BMC Biotechnol, sept23;2(1):17

3. Dharya,S., and Vidhu, A., 2013. Phytochemical Potential of Acanthus ilicifolius. J. Pharm Bioallied Sci. 5(1) p. 17-20

4. Johannes, E., dan Sri Suhadiyah., 2016. Analisis kimia dan Kandungan Antioksidan dari Ekstrak Daun Jeruju Acanthus ilicifolius .Bio wallacea Jurnal IImiah ilmu Biologi. Vol. 2 No. 2 p. 116-120. ISSN 2442-2622.

5. Konveden and Merugen., 2011. Efek of Medicinal Plant on The mosquito vectors from The different Agroclimatic Regions of Tanul Madu, India. Advan Environ Biol. 5(2) 335-344.

6. Mary Ann lila., 2004. Anthocyanin and Human Health An Invitro Investigative Approach. J. Biomed Biotechnol. 5. 306-313.

7. Meyer, Ferrigni, Putnam, Jacobsen, Nichols, Mc. Laughlin., 1982. Brine Shrimp: A Convenient General Bioassay for Active Lant Constituent, Plant Medica, Vol. 45.

8. Widodo, G.P., 2012. Mechanism of Action of Cumarin against Candida albicans By SEM/TEM Analysis. ITB. J. Sci. 145-151. 